\title{
WHAT PLACE HAS AN EMIGRATION PAST IN AN IMMIGRATION PRESENT? ITALY AND IRELAND COMPARED
}

\section{IRIAL GLYNN}

\begin{abstract}
Sommario
$\mathrm{Nel}$ diciannovesimo e ventesimo secolo milioni di Irlandesi e di Italiani emigrarono verso diversi paesi del mondo alla ricerca di una vita migliore. Le persone che hanno lasciato $i$ confini irlandesi sono stati spesso rappresentati come esuli dallo stato irlandese, e costantemente commemorati in coerenza con le tradizionali idee nazionaliste irlandesi. Diversamente, I'Italia non disponeva di una simile narrativa coloniale a cui far riferimento, e dunque lo stato italiano era riluttante a commemorare un passato di emigrazione che dimostrava l'incapacità dello stato a provvedere alle necessità dei suoi cittadini. Ironicamente, questa distinzione è diventata percettibile nei dibattiti contemporanei sull'immigrazione. In Irlanda, nei primi dibattiti che hanno avuto luogo tra la metà e la fine degli anni '90, gli attori pro-immigrazione hanno evocato in maniera costante la memoria della passata emigrazione irlandese, per indurre nei nativi irlandesi compassione verso i nuovi arrivati. Questa narrativa è stata tuttavia invocata meno frequentemente negli anni più recenti, da quando la compassione per gli immigrati è iniziata a declinare. In Italia, la storia di emigrazione del paese si è fatta notare soprattutto per l'assenza dai dibattiti sull'immigrazione. Quello che entrambi i casi dimostrano è che il passato viene ricordato soltanto se è in accordo con le necessità del presente.
\end{abstract}

Millions of Irish and Italians migrated throughout the nineteenth and twentieth centuries to countries all over the world in search of a better life. The Irish state, through constant commemoration, often represented Irish emigrants as exiles escaping colonialism and its 
legacy. In addition to embracing this official version, the popular memory of migration often associated the emigrant experience with economic struggle. Both memories invited frequent comparisons to others that had suffered similar imperial and economic difficulties. By contrast, the Italian state had no nationalist narrative to call upon to explain the massive exodus from its lands ${ }^{1}$. The state remained reluctant to commemorate the country's emigrant past because most people actually left in order to attain an adequate standard of living the Italian state was unable to underwrite. Though the national memory of migration was weak, a popular memory still existed; but this focused predominantly on the Italian state's failure to support the plight of its citizens abroad. Unlike Ireland's archive of suffering, which was open to all who could relate to the Irish experience, the Italian archive could only be referenced by Italians. Ironically, these distinctions became discernible in the first immigration debates that took place in both countries in the 1990s. In Ireland, pro-migrant actors consistently evoked the memory of past Irish emigration to induce sympathy amongst natives for newcomers. By contrast, references to Italy's migration past - of emigration and internal migration - were conspicuous only by their near-absence from immigration debates.

To expound and justify these assertions, this article is split into three parts. First, the scale of emigration that occurred from these two countries will be briefly highlighted. The second section will seek to discover what memory of migration developed in Ireland and Italy and why. The last section will discuss what impact the memory of migration - or its absence - had on immigration debates in Ireland and Italy.

Apart from government-supported emigration to Italy's colonies during fascism; an experience post-war Italy anxiously tried to forget. 


\section{Emigration}

To give an indication of the influence emigration had on Irish and Italian societies, this section focuses briefly on the extent of the departure. Between 1850 and 1913, over 4.5 million Irish people left their homeland for North America, England and Australia. As a consequence, the island's population dropped by almost a third (Hatton \& Williamson 1993:575). Though Italy's population steadily increased from 27.6 to 35.7 million between 1871 and 1911 (Del Panta 1996:134), it did so without over 13 million Italians, who left their country of birth between 1876 and 1914 (Rossoli 1978:345).

For many Irish people, the Famine represented the final ultimatum before deciding to leave their homeland. Declining demand for agricultural labour and the fall of Irish wages in comparison with the United States inclined millions to follow the Famine exodus (Doyle 2007:213). Men and women left in approximately equal numbers and, perhaps as a consequence, few returned (Hatton \& Williamson 1998:76 and 84).

Italy had a large population surplus in the late nineteenth century, with demand often outweighing supply. To escape the growing poverty, many chose to leave their homeland for Europe and the Americas. At the turn of the twentieth century, the promise of earning high wages meant that many turned to North America. While emigration from northern Italy to neighbouring European countries and South America had dominated emigration in the last quarter of the nineteenth century, in the first quarter of the twentieth century most emigrants hailed from southern Italy.

Though the southern part of Ireland achieved its independence from British rule in 1922, people of all religious persuasions continued to depart. Many moved to Britain because of America's decision to enact a number of restrictions on immigration. From 1945 onwards, post-war Britain offered another pull factor. Not only did the country need migrants to fill labour shortages after the Second World War but Attlee's Labour government initiated a generous and 
comprehensive welfare system. Emigration from Ireland only stalled in the 1970s because of the relative modernisation of the Irish economy following decades of isolationist policies (Foster 2007:7-36). Despite emigration reoccurring in the 1980s, Ireland received a net inflow of migrants from the early 1990s onwards.

Emigration from Italy recommenced following the First World War, but it never reached the heights of pre-war days. New American immigration restrictions introduced also limited Italian migrants' options considerably. Simultaneously, analogous developments took place across most of Europe, to be followed later by Brazil and Argentina as global economic depression set in after the 1929 Great Wall Street Crash. In the early 1920s Mussolini had seen emigration as a remedy for unemployment and as a way of spreading fascism throughout the world (Fortier 2000:71) but by the late 1920s it became illegal, concluding what Ipsen (1996:62) termed 'the Fascist transition from emigration encouragement to tolerance to repression'. A noticeable exception was emigration to Italy's colonies, which the regime still promoted.

After the fall of fascism and the end of the Second World War, emigration began to reoccur; though it again failed to reach the peak of a half-century before. Indeed, many of the emigrants that went to neighbouring European countries after the Second World War later returned to Italy's "economic miracle", which began in the 1950s. Significant economic growth in Italy actually led to approximately nine million people migrating within the country from the 1950 s to 1970s (Ginsborg 1990:219). Most transferred from rural areas - the South, the islands and the Veneto region - to industrial cities located predominantly in the North and especially Turin, Genoa and Milan (Alasi \& Montaldi 1975:30-1). From the 1970s, Italy began to receive a positive net inflow of migrants made up predominantly of returning migrants, although some foreign migrants also arrived.

The scale of emigration that occurred - and internal migration in the case of Italy - was enormous. But what memory did this produce and why? 


\section{What past for the present?}

Pierre Nora (1989:8) stated that memory is "vulnerable to manipulation and appropriation". Bal (1999:vii) concurred: memory, in his opinion, could be invoked "to mediate and modify difficult or tabooed moments of the past". Wertsch (2002:67) believes the modern state, with its hegemonic capacity to control many of the resources involved in remembering, is particularly adept at providing its members with certain accounts of the past. As Aleida Assmann (2006:216) affirms, states do not 'have' a memory, they 'make' a memory with the aid of symbols, texts, images, rites, ceremonies, places, and monuments. Such a political memory is based on selection and exclusion, especially if it means stabilizing and unifying a certain memory to promote the state's own goals (Phillips 2004:8). This section will try to discover what memory of migration the Irish and Italian states attempted to transmit to their citizens and why? It will also seek to determine how this political memory of migration was received. Confino (1999:1397) has remarked that memory commingles with, and is dependent on, its reception; hence it is important to ask what memory of migration Irish and Italian people habitually shared amongst their peers via different forms of oral communication.

\section{Ireland}

Irish secular and religious leaders throughout the nineteenth and early twentieth centuries regularly blamed continuous emigration on British rule. This association tallied well with the traditional interpretation that had long existed in Irish lore linking emigration with exile (Miller 1990:93). Of course, by constantly commemorating Ireland's Famine emigrants, the state had a perfect medium to transmit such a memory. Yet the majority of post-Famine emigrants left voluntarily; no one forced them to depart. Nonetheless, the image of involuntary 
departure "remained prevalent, still colouring the letters and memoirs of ordinary Catholic emigrants as well as songs and ballads, political speeches, and clerical sermons" (Miller:92). For Irish political leaders, such as Daniel O'Connell in the 1830s, John Mitchel in the 1850s, Charles Stewart Parnell in the 1890s and Padraig Pearse in the 1910s to name but a few - this account went hand in hand with contemporaneous nationalist sentiments.

In the decades after the Free State gained its independence in 1922, this myth was open to scrutiny because of continuing emigration from the country to England, especially in the 1940s and 1950s. Indeed, one commentator observed in 1953 that if emigration continued, the "Irish will virtually disappear as a nation and will be found only as an enervated remnant in a land occupied by foreigners" (O'Brien 1953, quoted in Delaney 1998:42). Seen with such trepidation, emigration understandably became the source of vigorous political debate in the country. This was augmented further by the Irish Catholic Church's concern for the fact that women made up the majority of those leaving (Daly 2006). Often, politicians and church leaders sought to reverse emigration by implying that it represented a sort of national betrayal, with Eamon De Valera, the Prime Minister at the time, observing in 1951 that "not only did they [emigrants] fail to improve their own circumstances by going abroad, but they leave enterprises for the development of our national resources without sufficient labour to enable progress to be made as rapidly as we would desire" (Gavin $2002: 157)^{2}$. Fintan O'Toole believes that it was only when the American president, John F. Kennedy, came to Ireland in the early 1960s that the negative connotation associated with emigration from Ireland after independence disappeared. Kennedy represented the positive side of emigration; the emigrant made good. He proudly told his Irish audience in June 1963: "Most countries send out oil, iron, steel or gold, some other crops, but Ireland has only one export and that is people (O'Toole 1997:52). As O'Toole surmised, Kennedy

2 The first was untrue, the second negligible. 
allowed Irish people to embrace their emigrant past rather than overlook it:

[Kennedy: ] 'I wonder before I go, if I could find out how many citizens here have relations in the United States? Do you think you could hold up your hands if you do?' [...] For decades these people in these crowds had listened to politicians and churchmen talking about the disgrace, the shame, the scandal of emigration [...] In the unseemly rush to claim Kennedy, we also had to claim all those other scattered families or ours, inglorious and unglamorous as they were. Those arms that reached out to him also had to grab a painful history [...] We faced the world thereafter with less innocence, less gullibility, more confidence and more clarity. (O'Toole 1997:50)

In the ensuing decades, emigration from Ireland manifested itself in a particular form of Irishness, associated with both colonial and economic hardship. As Gray (2002:131) illustrated, the Famine migrants, through constant state commemoration, became the "'authentic' Irish migrants, the traumatic, but genuine origin of 'Irish emigration". Perhaps reflecting the impact this had on the Irish character, one need look no further than Ireland's most popular song, The Fields of Athenry. Composed in the 1970s, it is still sung today at a variety of local, provincial and international sporting events involving Irish and Irish-linked teams. Fittingly, it recounts the exile of an Irishman during the Famine and his banishment from his beloved homeland: "For you stole Trevelyan's ${ }^{3}$ corn/So the young might see the morn/Now a prison ship lies waiting in the bay/ Low lie the Fields of Athenry/Where once we watched the small free birds fly".

3 Charles Edward Trevelyan was the Assistant Secretary to the British Treasury from 1840 to 1859 and was in charge of the administration charged with providing relief to the victims of the Irish Famine (1845-1849). 
Nonetheless, popular culture also focused on the poverty and destitution that prompted many Irish migrants to leave and compared it to the arduous experiences of others elsewhere, especially Africans and African-Americans. The Irish felt they could relate to the oppressed and the hungry everywhere because of their own experiences. In the words of the novelist Roddy Doyle: it was simple, "The Irish were the Blacks of Europe" (Doyle 1987). Extending this theme, Bono, the lead singer of U2 and the so-called 'white nigger', wrote: "The Irish, like the blacks, feel like outsiders. There's a feeling of being homeless, migrant [...]" (Hewson 1988). In the 1990s, this approach was given further leverage by the Irish president, Mary Robinson. Speaking at a commemoration to Famine migrants in Canada, she told listeners: "as a people who suffered and survived [...] our history does not entitle us to a merely private catalogue of memories" (Gray 2002:131). The implication was clear: the Irish, because of their own traumatic experiences, had to relate their own memories of past injustices with contemporary ones around the world.

\section{Italy}

Though negative stereotyping of Italians abroad, especially in the United States - where Italians were often linked to criminality inclined the Italian state to ignore rather than to celebrate its citizens abroad, the most significant reason for the state's failure to sufficiently honour its emigrant past related to its own central role in the experience. To commemorate the country's emigration history was to commemorate the state's failure to provide for its people. Unlike in Ireland, there was no nationalist myth to employ. Instead, it was clear to all that Italians left in an attempt to attain what the Italian state failed to bestow: an adequate living for all its citizens. As Negri (1997:44) records, the emigrant population was "defeated in the struggle to gain land, to improve its lot, to pursue that little bit of happiness that represents one of the great founding tenets of democracy". In order to avoid self-criticism, the Italian state seemed 
to avoid remembering the country's long, often traumatic emigration history; thereby creating a weak national memory of emigration in the process. The Italian state's continuous disinclination to officially remember the plight of millions of its emigrants has meant that the Italian memory of emigration has been largely carried out in private. As one Italian politician recently surmised:

The migration experience of Italians has not yet been elaborated in the collective culture, there is not even a collection of experiences in the reconstructed historiography, nor have memories, images, symbols been produced. One remembers only the grind; the private adventure has not been integrated into our national history, it does not make up part of our collective ethos, it does not feed the public feeling and ethic. (Turco 2005:11)

Whilst many Irish songs and poems lamented leaving their beloved land, Italian equivalents often used their grief to bemoan the Italian state. As one traditional song recalled, the feeling amongst emigrants was often hostile to the Italian state: "Damn Italy, let's get outta here" ${ }^{\text {" }}$ Theirs was not a victim diaspora, like the nationalist myth surrounding Irish emigration. Furthermore, because the majority of Italian emigrants left in the decades following the largely artificial unification of the country, many felt muted emotional attachment to a state that meant little to them (Guglielmo \& Salerno 2003:10). "Italianită", according to Gabaccia (2003:77), "reside[d] in the humble details of everyday life, not in the glories of any nation or its state". Mussolini's attempts to change this led to the establishment of various fasci (social clubs) dotted throughout the diasporic world, but these closed down soon after Mussolini's fall from power (Fortier 2000:74).

4 Campagne venete, taken from Gabbacia 2003:58. 
After the Second World War, successive governments, led by the Christian Democrats, saw emigration as offering a viable solution to the country's unemployment and underemployment problems (Colucci 2002:599). This in turn led the Italian government to negotiate a number of bilateral deals with other European states. Nevertheless, many emigrants felt that the state's interest in their wellbeing ended when they crossed the Italian border into another country. While the unions, the Church and close knit communities from home were often there to guide emigrants abroad, the state played little or no role in their daily lives, leading many emigrants' memories to be marked with a certain mistrust of Italian institutions (Colucci 2002:603). This displeasure manifested itself in protests after the Marcinelle mining disaster in Belgium in 1956, when 136 Italian miners lost their lives. Italy had signed a deal with Belgium in 1946 so that it received cheap coal in exchange for a steady flow of Italian mineworkers but Italian emigrants felt they received nothing from the state in return. As one song declared, the state was only interested in emigrants' remittances; not their health: "L'emigrante ha salvato la lira/lavorando in terra straniera/ma il governo italiano ci spera. Non appena passò la frontiera/si può essere offesi e insultati/o morire in miniera ammazzati. Il governo italiano ha interesse/solamente alle

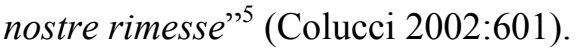

Internal Italian migrants experienced similar difficulties to emigrants when they moved from rural areas in the South and northeast to northern industrial cities in the 1950s and 1960s. Approximately 20 percent (Fofi 1964:9) of the Italian population migrated from one region to another during the 'economic miracle', where they subsequently encountered problems analogous to those of Italian emigrants abroad. They frequently worked illegally, often in hazardous conditions, and the persistent application of fascist laws

5 A rough translation might read, 'The emigrant has saved his lira/working in a foreign land/but the Italian government leaves him. Just when he has passed the border/he can be offended and insulted/or die in a mine. The Italian government is interested/only in our remittances' 
against urbanisation hampered their search for accommodation until the late 1950s, leading many to build their own housing (Alasia \& Montaldi 1975:29-30). Migrants, especially from the South, also suffered considerable discrimination from locals because of their perceived differences (Fofi 1964:251).

The state was seen by many to be an uninterested bystander in the affairs of migrants within the state and abroad. Accordingly, Italians often associated migration with a negative connotation of Italy, thus contributing to the already sizeable nativist archive of dissatisfaction amongst Italians towards the Italian state.

With Italy's rapid move towards modernization in the late 1950s and 1960s, Martelli (2001:476) surmised that images associating the country with poverty and suffering became unwelcome in Italian society. Thus the thousands of emigrants that returned to Italy in the 1960 s and 1970s often had to withhold any memories of financial hardship they envisaged whilst abroad. This aversion to evoking images of Italy's poorer past continued into the 1990s. As Campani (1993) argued, Italy is now a fully fledged modern Western nation that has left aside its potential role as a mediator between South and North, based on its Mediterranean identity and geography ${ }^{6}$. Though several filmmakers, novelists, academics and new emigrant museums have since captured the experiences of Italian migrants, comparisons between Italians' arduous experiences and those of others were rare. As a result, the memory of migration in Italy rarely led to collective feelings of camaraderie and understanding with any non-Italians.

6 Campani (1993: 532) states that there was a "conception of Italy as a mediator between the North and the South (especially between North Africa and Europe) inside a Mediterranean space, corresponding to a long history of exchange and to possession of a common culture $[\ldots]$ but now it has been rejected in parallel with Italy's alignment with the western world, after a long period of popular mobilization and struggle". 


\section{Changing Identities: From out-migration to in-migration}

Today, Ireland's immigration population stands at nearly half a million (CSO 2007) - or approximately 10 percent of the Irish population; Italy's immigrant population measures between 3.5 million and 4 million (Caritas 2008) - or between 5.8 and 6.6 percent of the Italian population. Public, political and media opposition to certain groups of migrants, based on perceived cultural, physical and economic threats, quickly became apparent in both countries after the arrival of significant numbers of immigrants. To offset such resistance, pro-migrant actors used a mixture of moral, communitarian and humanitarian rationales to evoke empathy amongst natives for these newcomers in both countries. Pro-migrant actors in Ireland also used the memory of past Irish emigrants to invoke empathy with asylum seekers - the main targets of anti-immigrant hostility. By implying that they shared a common experience, Irish people were made to feel they had a moral debt or responsibility to help these people (Gray 2004:9). In contrast, comparisons between "clandestini" - the targets of the majority of anti-immigrant vitriol in Italy - and former Italian emigrants were seldom made by pro-migrant actors, even though it could be argued that they shared much in common. Later debates in both countries, however, were to reveal the fragile nature of memories based on compassion and understanding with others.

A large number of non-Irish migrants accompanied returning Irish emigrants when the Irish economic boom began in the mid 1990s. Most of the arrivals came with work permits or applied for asylum. While the country only had to contend with thirty-nine asylum applications in 1992, by 1997 this had risen to nearly four thousand before reaching its crescendo of almost twelve thousand in 2001. This massive increase represented, according to one journalist, the largest influx of those seeking shelter in the country since 'the Celts were driven west by the Romans' (Cullen 1997:11). The fact that it took an average of two years to deal with every asylum case - because the 
system in place dealt normally with only thirty to sixty cases a year meant that a huge backlog in applications rapidly amassed. Because the state had a responsibility to house, feed and provide for these asylum seekers - who were barred from employment during the application procedure - a noticeable surge in public, political and media opposition to asylum seekers became discernible. To counter this hostility, pro-migrant actors frequently referenced past Irish emigrants in an attempt to evoke compassion with asylum seekers. This rhetoric initially met with much resonance amongst the public, politicians and the media alike; before weakening as opposition to asylum seekers increased.

In the first meaningful debate on asylum in 1995, one politician commented: "[T] he status of refugees is an issue which should strike a chord with every man, woman and child here who has any grasp of Irish history, our history books being littered with the names and deeds of those driven from our country out of fear of persecution" (O'Donogue 1995, cited in King 2002:202). Three years later, when the very same politician attempted to introduce more restrictive asylum policies in his new role as Justice Minister, various politicians again referenced Ireland's own migration heritage. One stated that Ireland's "history requires us to be generous and just" (McManus 1998), while another attacked the government's policy on similar but more explicit grounds:

We are showing a version of ourselves that is depressing and mean. I imagine there is more decency in ordinary Irish people who, as already stated, have the ethic of memory. Most families in Ireland have relatives who went abroad $[\ldots]$ and they want to see the emergence of a kind of dignity and solidarity. (Higgins 1998, emphasis added)

A 2000 survey seemed to indicate that these metaphors between Ireland's past emigrants and more recent immigrants affected public 
opinion somewhat: sixty percent agreed that a more generous approach ought to have been taken with asylum seekers because of Ireland's history of emigration and their current prosperity (Rafter 2000:1). But the reaction to another question in the same survey highlighted the ambiguous nature of Irish attitudes towards asylum seekers, as 74 percent of those questioned stated their preference for a strict limit to be placed on the number of asylum seekers allowed into the country. In line with growing resentment towards asylum seekers, references to Irish emigrants became less habitual. Those in favour of restricting asylum numbers actually began to alter the memory of Irish migrants to coincide with this mounting intolerance for asylum seekers. Irish emigrants, they remarked, never scrounged off receiver states like asylum seekers: they worked hard. The contraposition to asylum seekers, who were disallowed from working by the state while their application was under consideration and hence had to live off state benefits, was obvious. The memory of the past, it seemed, could always be tailored to suit the present. As Kendal Phillips (2004:4) remarked, "If the existence of a healthy and functioning public is intertwined with its capacity for remembrance, then the gradual erosion by forgetting must represent a grave danger".

In direct contrast to Ireland, pro-migrant actors in Italy rarely alluded to Italy's rich migration history in immigration debates due to the imperceptible political memory of migration in Italy and the exclusive nature of Italians' memories of migration. Instead of underlining parallels between immigrants and Italians, politicians stressed the disparities between the two - a development that would become more even more evident after the collapse of the Italian Communist Party and the Christian Democrats.

The Italian Communist Party had adopted, included and eventually integrated many of the southern Italian migrants who moved to northern Italy in the 1950s and 1960s under the rubric of class struggle and socioeconomic justice. But its inability to attain power in the 1970s and 1980s and its ultimate demise in early 1991, after the fall of communism in Europe, meant this never occurred with foreign 
migrants in Italy in the 1990s and 2000s. As Pero noted, whilst the Communist Party's successors' rhetoric remained inclusive, its practices were frequently exclusive (Pero 2007).

The Christian Democrats reaction to immigrants was hazy, as was demonstrated by its reaction to the two waves of Albanian migration to Italy in spring of 1991 and August 1991. After days of indecision, the first influx, measuring approximately 26,000 , received temporary visas and Giulio Andreotti, the leader of the government at the time, asked Italians to follow his own personal example by symbolically adopting Albanians. As one of Andreotti's colleagues in the Christian Democrat party explained to parliament, these newcomers shared several traits with Italians:

Attention must be drawn also to another fact: those who disembark in Italy [...] even in their weakness, even in their fragility, even in their destitute appearance, are people with their own families, who in fact have a culture [culto] of family, who love their own land, who have a tradition, a history of utmost respect that has many similarities to our history and our traditions. (Piccoli 1991)

But this sympathetic attitude towards the Albanians, and immigrants more generally, began to slowly digress over the ensuing months as public opposition to immigration grew. Opinion polls released several months after the first Albanian incident seemed to reflect the growing enmity to immigrants in the country, with La Repubblica arguing that the 'Albanian effect' had helped to increase public opposition to immigrants compared to previous years (Bonerandi 1991:20). Much of this resistance related to Italians' fear of immigrants. As one expert recorded, 55.4 percent of Italians surveyed felt that there was a clear correlation between increasing criminality and the rise in the numbers of immigrants (Bonifazi 1998:225). In response, the Christian Democrat-led government adopted a markedly tougher stance when 
almost 20,000 Albanians sailed (most of whom were on board the Vlora) into Bari on 8 August 1991.

The state immediately classified the situation as a military and police problem rather than a humanitarian one (Ruggeri 1991:3). In complete contrast to the first Albanian incident, Italian police and military forced the Albanians into Bari's football stadium for several days before forcefully expatriating them. The disparity of the political responses to the two Albanian episodes was astonishing. In the wake of such a contrasting reaction to the two Albanian incidents, one journalist felt compelled to ask:

What kind of a strange country is this? It is a country in which the government, personified by the President of the Council first symbolically adopts three young Albanian refugees and then locks 16,000 people in a concentration camp for three days without water and food. [...] someone still has to find the courage to explain to Albanians, and to Italians, if this is really a country of fairytales in which three desperate people can become sons of the head of government or whether it is an inferno that should not be approached. (Palombelli 1991:1)

Even though the Christian Democrats had reacted so harshly to the second Albanian incident, some empathy still existed within the party to the plight of migrants because of the party's links to the Catholic Church, which consistently voiced its support for migrants. Yet, this capacity diminished over the ensuing years as Italy experienced its biggest political crisis since the birth of the post-war Republic. The corruption scandal that came to be known as Tangentopoli (roughly translated as 'Bribesville') inclined many of the country's most famous political figures to vanish from politics, along with the parties they represented, including the Christian Democrats, the Socialist Party, the Italian Republican Party, the Italian Socialist Democratic Party and the Liberal Party. 
Those parties that stepped into the political vacuum Tangentopoli created, such as the neo-fascist Alleanza Nazionale (AN) ${ }^{7}$, the amalgamated Lega Nord and, to a lesser extent, the newly formed Forza Italia, would bring the issue of immigration to the fore of public debate from the mid 1990s onwards, and especially in the runup to the 2001 and 2008 general elections. These parties repeatedly focused on the physical and cultural threats they claimed immigrants posed to Italian society. Though several figures from AN and Forza Italia acknowledged Italy's emigrant past, they never related this often traumatic experience to the similar predicaments contemporary migrants in Italy habitually faced, as concerns over security and control overrode any sense of compassion or understanding (Buonfino 2004:21-2).

\section{Conclusion}

Buonfino has recounted how Italian politicians from the AN and Forza Italia frequently differentiated between Italian emigrants of yesterday and migrants in Italy today by describing the former as 'entrepreneurs', 'skilled' migrants and 'hard working' people, and the latter as 'lazy', 'criminals', and 'illegals' (Buonfino 2004:22). In recent years, Irish politicians have begun to display similar sentiments as public hostility towards asylum seekers has mounted. Retaining a vivid memory of migration is therefore not emblematic of avoiding the build-up of anti-migrant sentiments amongst politicians, publics and media alike. Nonetheless, it is a useful tool for pro-migrant actors to employ in immigration debates to counteract the rise of antipathy towards migrants. Comparing newcomers to natives can harbour feelings of solidarity and similitude between the two when the national memory of migration is strong and inclusive, as the Irish case displayed. Conversely, when a weak and exclusive memory of

7 The Alleanza Nazionale (AN) replaced the Movimento Sociale Italiano. In doing so, the party's vote increased from 5.9 percent in 1987 to 12.7 in 1994 (Martini 1994:5). 
migration hinders pro-migrant actors from emphasising similarities between natives and newcomers, anti-immigrant rhetoric highlighting the inherent physical and cultural differences between the two instead becomes more widespread. This in turn leads to the growth in popularity of anti-immigrant political parties and the gradual adoption of more hard-line views on immigration among mainstream parties, as the Italian case is demonstrating all too vividly today.

(European Institute, Florence)

\section{Bibliography}

Alasia, F. \& Montaldi, D. 1975 Milano, Corea: Inchiesta sugli immigrati, Milan: Feltrinelli (1st ed. 1960).

Assmann, A.

2006 Memory, Individual and Collective. In: Goodin, Robert E. \& Tilly, Charles (eds.), The Oxford Handbook of Contextual Political Analysis, Oxford: Oxford University Press:210-224.

Bal, M.

1999 Introduction. In: Bal, Mieke; Crewe, Jonathan \& Spitzer, Leo (eds.), Acts of Memory: Cultural Recall in the Present:vii-xvii.

Bonerandi, E.

1991 Effetto albanesi. La Repubblica, 26 July:20.

Bonifazi, C.

1998 L'immigrazione straniera in Italia, Mulino: Bologna.

Buonfino, A.

2004 Politics, Discourse and Immigration as a security concern in the EU: A tale of two nations, Italy and Britain. Paper presented at the workshop "Who 
Makes Immigration Policy? Comparative Perspectives in a post9/11 World", Uppsala, Finland, 13-18 April 2004.

Campani, G.

Caritas Italia

Central Statistics

Colucci, $\mathrm{M}$.

Confino, A.

Cullen, $\mathrm{P}$.

Daly, M. E.

Delaney, E.
1993 Immigration and racism in southern Europe: the Italian case. In: Ethnic and racial studies, 16.3:507-535.

2008 Immigrazione: dossier statistico 2008: XVIII rapporto sull'immigrazione, Roma: Centro studi e ricerche IDOS.

20072006 Census, Cork: Irish Central Statistics Office (CSO).

2002 Il voto degli italiani all'esterno. In: Bevilacqua, P.; De Clementi, A. \& Franzina, E. (eds.), Storia dell'emigrazione italiana (Arrivi), Rome: Donzelli Editore:597-609.

1999 Cultural memory and cultural history: problems of method. In: American Historical Review, Vol. 102, no. 5: 1386-1403.

1997 Only surprise is how long refugee influx has taken to happen here. Irish Times, 17 May:11.

2006 Slow Failure: Population Decline and Independent Ireland, 1920-1973, Wisconsin: Wisconsin University Press.

1998 State, politics and demography: The case of Irish emigration, 1921-71. In: Irish Political Studies, 13(1):25-49. 
Del Panta, L.

Doyle, D.

Doyle, R.

Einaudi, L.

Favero, L. \& Tassello, G.

Fofi, G.

Fortier, A.

Foster, R.F.

Gavin, B.
1996 Dalla metà del settecento ai nostri giorni. In: Del Panta, L. et al (eds.), La Popolazione Italiana dal Medievo a Oggi, Editore Laterza: Bari:131-212.

2007 The Remaking of Irish America, 18451880. In: Lee, J.J. \& Casey, M.R. (eds.), Making the Irish American: history and heritage of the Irish in the United States, NY: New York University Press:213-252.

1987 The Commitments, Dublin: King Farouk.

2007 Le politiche dell'immigrazione in Italia dall'Unità a oggi, Bari: Laterza.

1978 Cent'anni di emigrazione italiana (1876-1976). In: Rossoli, G. (ed.), Un secolo di emigrazione italiana: 18761976, Rome: Centro studi emigrazione:9-64.

1964 L'immigrazione meridionale a Torino, Milan: Feltrinelli.

2000 Migrant Belongings: Memory, Space and Identity, NY/London: Berg.

2007 Luck and the Irish: A brief history of change c. 1970-2000, London: Allen Lane.

2002 From Union to Union: Nationalism, democracy and religion in Ireland, Dublin: Gill \& Macmillan. 
Ginsborg, P.

Guglielmo, J.

Gray, B.

Gray, B.

Halbwachs, M.

Hatton, T. \&

Williamson, G.

Hatton, T. \&

Williamson, G.

Hewson, P.

Higgins, M.
1990 History of Contemporary Italy: Society and Politics 1943-1988, London: Penguin.

2003 Introduction: White Lies, Dark Truths. In: Guglielmo, J. \& Salerno, S. (eds.), Are Italians White? How Race is Made in America, London/NY: Routledge:1-16.

2004 Remembering a 'multicultural' future through a history of emigration: Towards a feminist politics of solidarity. University of Limerick, Department of Sociology Working Paper Series, 2004.

2002 The Irish Diaspora: Globalised Belonging(s). Journal of Irish Sociology, 11(2):123-144.

1992 On Collective Memory, Chicago/ London: University of Chicago Press (translation by Lewis A. Coser).

1993 After the Famine: Emigration from Ireland, 1850-1913. In: The Journal of Economic History, 53(3):575-600.

1998 The Age of Mass Migration: Causes and Economic Impact, New York: Oxford University Press.

1988 Bono: the white nigger. In R. Kearney (ed), Across the frontiers: Ireland in the 1990s, Dublin: Wolfhound Press: 188-191.

1998 Dáil Éireann, Vol. 488, 11 March. 
Ipsen, $\mathrm{C}$.

King, J.

Martelli, S.

Martini, F

McManus, L.

Miller, K.

Negri, A.
1996 Dictating Demography: The problem of population in Fascist Italy, Cambridge: Cambridge University Press.

2002 Ireland abroad/broadening Ireland: from famine migrants to asylumapplicants and refugees. In: Walsh, Oonagh (ed.), Ireland Abroad. Politics and Professions in the Nineteenth Century, Dublin: Four Courts Press: 202-214.

2001 Dal vecchio mondo al sogno americano: Realtà e immaginario dell'emigrazione nella letteratura italiana. In Piero Bevilacqua, Andreina De Clementi \& Emilio Franzina (eds.), Storia dell'emigrazione italiana (Partenze), Rome: Donzelli Editore:433-487.

1994 Fini: "Senza di noi non si governa", La Stampa, 29 March:5.

1998 Dáil Éireann, Vol. 488, 10 March 1998.

1990 Emigration, Capitalism and Ideology in Post-Famine Ireland. In Richard Kearney (ed.) Migrations: The Irish at Home and Abroad, Dublin: Wolfhound:91-108.

1997 Italy, Exile Country. In Beverly Allen (ed.), Revisioning Italy: National Identity and Global Culture, Minneapolis: University of Minnesota Press:43-51. 
Nora, P.

O’Toole, F.

Palombelli, B.

Pero, D.

Phillips, K.

Piccoli, F.

Rafter, K.

Rossoli, G.

Ruggeri, C.

Turco, L.
1989 Between memory and history: Les lieux de Memoire. Representations, No. 26:7-24.

1997 The lie of the land: Irish identities, NY: Verso.

1991 Così si è spezzato il sogno italiano, $L a$ Repubblica, 11 August.

2007 Inclusionary Rhetoric Exclusionary Practices. Left-wing Politics and Migrants in Italy, London: Bergahn Books.

2004 Introduction. In Kendall R. Phillips (ed.), Framing Public Memory, Tuscaloosa: University of Arizona Press:1-14.

1991 X legislatura: Camera dei DeputatiDiscussioni, 8 March 1991:80632.

2000 Substantial majority of voters wants limits on refugee numbers, The Irish Times, 24 January:1.

1978 Un secolo di emigrazione italiana: 1876-1976, Rome: Centro studi emigrazione.

1991 Per i ministri è "un problema di ordine pubblico", Corriere della sera, 9 August:3.

2005 I Nuovi Italiani. L'immigrazione, $i$ pregiudizi, la convivenza, Milan: Mondadori. 
Wertsch, J.

2002 Voices of Collective Remembering, Cambridge: Cambridge University Press. 